\title{
PELESTARIAN MAKANAN TRADISIONAL KEJOS SBAGAI SUMBER KARBOHIDRAT DI DESA TARIKOLOT KECAMATAN JATINUNGGAL KABUPATEN SUMEDANG PROVINSI JAWA BARAT
}

\section{CONSERVATION KEJOS TRADITIONAL FOOD AS CARBOHYDRATE NUTRITIONS IN TARIKOLOT SUBDISTRICT JATINUNGGAL DISTRICT SUMEDANG PROVINCE JAWA BARAT}

${ }^{1}$ Risa Rahmalianti, ${ }^{2}$ Mirna Nur Alia A, ${ }^{3}$ Dony Riyadi.

Prodi Manajemen Industri Katering, Fakultas Pendidikan Ilmu Pendidikan Sosial

E-mail: risarahmalianti@gmail.com, 085314070172

\begin{abstract}
This research is focused on discuss about traditional food which is based on cassava, it is called kejos and it is rarely found in Tarikolot subdistrict Jatinunggal district Sumedang Province Jawa Barat now. This traditional food have a good taste and has a property glut Such as rice. Kejos which is based on cassava has a good potensial, because it can grow in every weather and every year. And it is also can be found everywhere.

There is a lot of nutritions in cassava such as carbohydrate. The level of carbohydrate in cassava if we compared with rice is the third. First is rice and the second is corn. This traditional food is also has a story to citizen in Tarikolot that time. It will be disappointed if this traditional food disappear.

Therefore, the writer make some innovation to make this traditional food become popular.

Keywords: traditional food,conservation effort, kejos

ABSTRAK

Karya ilmiah ini fokus membahas mengenai makanan pokok tradisional berbahan dasar singkong yang saat ini keberadaanya sudah jarang ditemukan khususnya di Desa Tarikolot Kecamatan Jatinunggal Kabupaten Sumedang. makanan tradisional ini terkenal dengan sebutan kejos di Desa Tarikolot, makanan ini memiliki sifat yang mengenyangkan sama seperti beras. Kejos yang berbahan dasar singkong memiliki potensi yang bagus karena singkong mudah ditemukan dimanapun

Dengan melihat keadaan saat ini yang dimana beras mahal, kenapa tidak memanfaatkan bahan pangan lokal yang mudah di produksi dan tumbuh subur di setiap daerah.. Kejos memiliki kandungan karbohidrat yang hampir sama dengan beras, jika melihat kandungan yang terdapat dalam singkong, singkong adalah sumber karbohidrat ketiga terbesar setelah beras dan jagung.

Makanan tradisional ini juga memiliki cerita tersendiri bagi masyarakat Desa Tarikolot pada saat itu, sehingga akan sangat disayangkan jika makanan ini hilang.

Oleh karena itu, peneliti melakukan inovasi supaya makanan tradisional ini bisa lebih menjadi popular di masyarakat.
\end{abstract}

Kata kunci: makanan tradisional, upaya pelestarian, kejos 


\section{Pendahuluan}

Makanan tradisional merupakan fenomena kebudayaan yang semakin di teliti keberadaannya, semakin kita bangga terhadapnya dan semakin ingin mengetahui tentangnya, kebudayaan juga dapat menentukan makanan itu dapat dimakan atau tidak, sekaligus memberi cap atau mengesahkannya menjadi ke khasan suatu daerah. Dengan demikian, makanan bukan sekedar untuk mempertahankan hidup, melainkan juga untuk mempertahankan kebudayaan. (Trisna Kumala Dewi,2011, hlm.1)

Makanan tradisional saat ini sudah sangat jarang ditemukan karena adanya perubahan zaman. Sebagian masyarakat menganggap makanan dan tradisional adalah panganan yang sudah ketinggalan zaman, sehingga sekarang makanan tersebut sudah ditinggalkan oleh masyarakat, dan mulai beralih pada kehidupan modern. padahal makanan tradisional adalah wujud warisan nenek moyang yang harus tetap dijaga dan dilestarikan keberadaanya.

(Arum Kusmaningttyas,2013,hlm.1)

Selain itu, makanan tradisional adalah salah satu yang menjadi daya Tarik wisata di suatu daerah, kegiatan tersebut dinamakan wisata kuliner. Menurut Yuni Maharani (2011) jenis-jenis kuliner di Indonesia diagi menjadi dua kategori besar, yaitu makanan berat dan makanan ringan. Makanan berat merupakan kebutuhan pokok bagi kehidupan manusia. yang berfungsi sebagai sumber karbohidrat. Makanan pokok disini berarti makanan yang menjadi bahan pokok untuk makanan sehari-hari dengan tujuan untuk memenuhi kebutuhan badan. (kemendikbud,2014,hlm.11).

Bahan dasar pangan untuk memenuhi asupan karbohidrat untuk tubuh manusia bisa didapatkan dari berbagai macam bahan pangan. Seperti padi, gandum, ubi, singkong, jagung dan yang lainnya. Di Indonesia sendiri bahan pangan di atas mudah ditemukan terkecuali gandum. Indonesia adalah negara yang iklimnya bisa ditumbuhi berbagai macam bahan baku makanan. Indonesia adalah negara yang kaya akan kekayaan alam dan kebudayaan. Kesenian, rumah adat, suku, Bahasa, dan makanan. Ada banyak sekali makanan khas Indonesia yang mencirikan suatu daerah. Misalnya nasi padang, nasi pecel, nasi liwet, dan lian-lain. Dari sekian banyak makanan yang ada di Indonesia, peneliti tertarik kepada makanan tradisional kejos, yaitu makanan pokok pengganti beras yang terbuat dari singkong. Selain bahan baku kejos dapat ditemukan dengan mudah di desa Tarikolot, Kejos merupakan makanan tradisional yang dikonsumsi masyarakat zaman dahulu sebagai makanan pokok. Kejos merupakan makanan yang dikategorikan makanan pokok Karena memiliki sifat yang mengenyangkan.

Indonesia memiliki tanah yang dapat ditumbuhi berbagai bahan pangan. Salah satunya adalah singkong. Menurut Winarmo (2004) Singkong adalah

Salah satu tanaman umbi-umbian yang banyak terdapat di Indonesia. Keadaan tanah yang subur dan letak geogafis Indonesia yang cocok untuk tumbuhnya tanaman ini, membuat singkong sangat melimpah keberadaanya di Indonesia. Singkong mengandung bahan karbohidrat ketiga terbesar setelah beras dan jagung yaitu sebesar $34,6 \%$. (hlm.53)

Penelitian ini berlangsung di Desa Tarikolot Kecamatan Jatinunggal Kabupaten Sumedang Provinsi Jawa Barat. Dimana kejos adalah makanan pokok pengganti 
beras yang sempat dikonsumsi oleh masyarakat desa Tarikolot. Kejos merupakan makanan yang dikonsumsi karena saat itu Indonesia belum memprioritaskan pertanian untuk memproduksi beras. Dan karena saat itu pertanian belum terfokus untuk menyejahterakan masyarakat, karena pada saat itu Indonesia sedang maengalami keterpurukan akibat penjajahan.

Begitupun yang terjadi di Desa Tarikolot, masyarakat desa Tarikolot saat itu mengandalkan singkong sebagai makanan pokok yang diolah menjadi kejos.

Di daerah ini Kejos sudah dikonsumsi sejak tahun \pm 1920 an. Menurut keterangan dari nenek Imi, kejos ini biasa dikonsumsi karena keterbatasan persediaan beras pada saat itu. Penyebabnya adalah pertanian di Desa Tarikolot masih belum mencukupi kebutuhan beras pada saat itu.

Filosofi kejos sendiri muncul karena kesengsaraan yang dirasakan oleh masyarakat sangatlah terasa pada saat itu, yaitu "Makanan zaman paceklik", begitu masyarakat desa menyebutnya. Hal ini disebabkan oleh para penjajah yang merampas hasil pertanian warga. Selain itu, adalah bibit padi yang jelek. Bibit padi pada saat itu hanya bisa dipanen selama setahun dua kali. Selain itu beras yang di konsumsi juga terbilang kurang enak untuk dimakan, rasanya kesat dan agak berbau. Hanya saja saat ini kejos sudah jarang ditemukan.

Padahal jika kejos ini memiliki banyak keunggulan yang tidak kalah dengan beras. Menurut Indah Widowati 2013 (hlm.1) memanfaatkan singkong sebagai bahan baku sangat besar seperti industry makanan ini. Selain sumber karbohidrat nya, Masyarakat juga mempercayai singkong sebagai salah satu obat untuk mencegah penyakit maag. Masyarakat juga lebih memilih kejos untuk di konsumsi karena bahan dasaranya terbuat dari singkong yang mereka tanam sendiri. Sehingga aman dari bahan berbahaya/ bahan kimia.

Berikut adalah komposisi nutrisi yang dimiliki oleh singkong.

Tabel 1.1

Komposisi Singkong /100gr

\begin{tabular}{|c|c|c|}
\hline No & Komponen & Kadar \\
\hline 1 & Kalori & 146,00 \\
\hline 2 & Air & 62,50 \\
\hline 3 & Fosfor & 40,00 \\
\hline 4 & Karbohidrat & 34,00 \\
\hline 5 & Kalsium & 33,00 \\
\hline 6 & Vitamin C & $30,00 \mathrm{mg}$ \\
\hline 7 & Protein & 1,2 gram \\
\hline 8 & Besi & $0,7 \mathrm{mg}$ \\
\hline 9 & Lemak & 0,30 gram \\
\hline 10 & Vitamin B1 & 0,06 \\
\hline
\end{tabular}

Sumber: Emil Salim tahun 2011:24

Berdasarkan tabel diatas kandungan gizi yang dimiliki oleh singkong cukup untuk memenuhi kebutuhan gizi manusia. Singkong memiliki kandungan karbohidrat yang cukup besar. Singkong juga memiliki kandungan serat yang tinggi. Singkong menjadi 
makanan yang mengenyangkan dan bisa menjadi makanan alternative sumber karbohidrat selain nasi.

Di desa Tarikolot sendiri, masyarakat yang tidak memiliki lahan untuk bertani dan sudah terbiasa menkonsumsi beras sudah mengeluhkan akan harga beras yang mahal. Meskipun ada beras bantuan dari pemerintah (bulog) rasanya kurang enak dan memiliki bau yang tidak sedap. Sehingga masyarakat sering mencampurnya dengan beras dari petani atau istilah yang mereka pakai adalah "digolosor". Bagi masyarakat yang tidak memiliki lahan pesawahan tentunya ini menjadi hal yang urgent ketika para pemasok beras saat ini memiliki pikiran yang keji dengan menghadirkan beras plastik dan beras yang tidak layak konsumsi.

Menurut Hidayah (2011) Perilaku konsumsi pangan masyarakat dilandasi oleh

kebiasaan makan (food habit) yang tumbuh dan berkembang dalam lingkungan keluarga melalui proses sosialisasi. Kebiasaan tersebut dapat dipengaruhi oleh lingkungan ekologi (ciri tanaman pangan, ternak, dan ikan yang dibudidayakan di lingkungan tersebut), lingkungan budaya dan system ekonomi. (hlm.89)

Budaya Indonesia yang saat ini sudah tidak bisa lepas dari makan beras. Masyarakat Indonesia mengkonsumsi lebih dari $130 \mathrm{~kg}$ per tahunnya. Keberadaan kejos saat ini sangat tergantung dari bagaimana kita sebagai masyarakat Indonesia memandang makanan tradisional sebagai warisan turun temurun dari leluhur kita. Saat ini keberadaan kejos di Desa Tarikolot sudah jarang ditemukan. Fungsi kejos sebagai makanan pokok di desa Tarikolot saat ini sudah dipandang sebelah mata karena gengsi. Selain itu saat ini masyarakat sudah terrbiasa mengkonsumsi beras atau nasi sebagai makanan pokoknya. Sedangkan saat ini produksi beras sudah mulai tidak produktif lagi dikarenakan pembangunan pemukiman dan alih fungsi lahan menjadi fasilitas umum.

\section{Metode Penelitian}

Pada bagian ini peneliti akan menjelaskan metode penelitian dan teknik pengumpulan data secara teoritis sebagai landasan dalam pelaksanaan penelitian yang akan penulis lakukan. Selain itu, peneliti akan menjelaskan mengenai tahapan persiapan dalam pembuatan skripsi, yaitu pengajuan tema, penuyusunan rancangan penelitian, mengurus perizinan, menyiapkan perlengkapan penelitian, dan proses bimbingan. Selanjutnya adalah pelaksanaan penelitian yang dimulai dari pengumpulan data, yang dilakkan dengan cara melakukan observasi dan wawancara. Setelah itu di bagian terakhir adalah memaparkan hasil observasi ke lapangan yang telah dilakukan.

Metode yang digunakan dalam penelitian ini adalah metode kombinasi, yaitu metode penelitian yang menggabungkan antara metode kuantitatif dan kualitatif dalam penyajian data. penelitian ini menggunakan mix method karena peneliti melakukan pengambilan data dengan menyebarkan instrument berupa kuesioner yang dalam penyajian data nya menggunakan pie chart. Dimana pengolahan datanya dilakukan dengan menjumlahkan partisipan yang berpatisipasi dalam penelitian ini.

Dalam penelitian ini peneliti menggunakan Nonprobability Sampling. Dalam penelitian ini peneliti menggunakan purposive sampling yaitu pengambilan sample sumber data yang didasarkan dengan pertimbangan tertentu. 
Untuk mendapatkan data tersebut peneliti harus memiliki teknik untuk mengumpulkan data. Peneliti menggunakan teknik wawancara. Ada beberapa teknik wawancara yang biasa digunakan dalam penelitian menurut Creswell (2013) yaitu sebagai berikut:

Wawancara kualitatif, peneliti dapat melakukan face-to face interview (wawancara berhadap-hadapan) dengan partisipan, mewawancarai mereka dengan telepon atau terlibat dalam focus group interview (interview dalam kelompok tertentu) yang terdiri dari enam sampai delapan partisipan per kelompok. (hlm.267)

Peneliti berusaha mencari narasumber yang dianggap berkopenten untuk memberikan informasi yang dibutuhkan, kemudian melaksanakan tanya jawab dengan melakukan wawancara kepada produsen kejos, masyarakat, apparat desa dan melakukan uji daya terima konsumen di GH.Universal.

Peneliti melakukan penelitian mengenai seberapa banyak masyarakat yang masih memproduksi kejos, seberapa banyak orang yang mengetahui kejos, dan bagaimana bisa kejos dikonsumsi di Desa Tarikolot ini.

Selain melakukan penelitian dengan cara wawancara, penelitian ini juga menggunakan referensi dari penelitian sebelumnya yang berkaitan sebagai pembanding atau hanya sekedar referensi. Menurut Weber (1980:9) dalam Lexy J. Meolong (2014) menyatakan bahwa kajian isi atau studi literature adalah metode penelitian yang memanfaatkan seperangkat prosedur untuk menarik kesimpulan yang shahih dari sebuah buku atau dokumen.

Berdasarkan hasil observasi yang dilakukan oleh peneliti dapat disimpulkan bahwa kejos di Desa Tarikolot masih diketahui oleh masyarakatnya. Hanya saja mereka sudah tidak lagi mengkonsumsi kejos sebagai makanan pokok utama.

\section{Hasil dan Pembahasan}

Dari penelitian yang dilakukan dapat dideskripsikan bahwa, ada tiga permasalahan yang dapat peneliti kaji dalam upaya pelestarian makanan tradisional ini yaitu, (1) bagaimana potensi kejos sebagai sumber karbohidrat di Desa Tarikolot Kecamatan Jatinunggal Kabupaten Sumedang Provinsi Jawa Barat. (2) Bagaimana upaya pelestarian Kejos di Desa Tarikolot. (3) Bagaimana peran PEMDA dalam upaya pelestarian makanan tradisional di Desa Tarikolot.

\section{Potensi kejos di Desa Tarikolot}

Berdasarkan data hasil wawancara menunjukan bahwa masyarakat Desa Tarikolot mengetahui kejos sebagai bahan pokok pengganti beras yang pada jaman dahulu dikonsumsi masyarakat sebagai sumber karbohidrat pengganti nasi. Peneliti melakukan wawancara kepada masarakat yang kebetulan sedang berada di rumah atau warga yang sedang berkumpul. Peneliti menanyakan hal dasar mengenai kejos seperti “ Apakah anda mengetahui kejos?' kepada warga dari usia <20, 20-30. 30-40, 40-50, >50. Penelitian menunjukan bahwa kejos masih familiar di Desa Tarikolot Kecamatan Jatinunggal Kabupaten Sumedang. hanya saja keberadaannya sudah jarang pada saat ini.

Desa Tarikolot adalah desa yang memiliki banyak lahan untuk pertanian, hampir di semua dusun memiliki lahan luas untuk menanam berbagai macam bahan pangan, contohnya singkong. Singkong sendiri sudah menjadi hasil pertanian yang ada setiap 
tahunnya di Desa Tarikolot. Di desa Tarikolot singkong menjadi bahan untuk membuat Keripik dan makanan lain seperti papais singkong dan kecimpring.

Singkong dijual dengan harga Rp.9000,00 per Kg, dengan kualitas yang baik. Singkong adalah bahan baku yang mudah ditemukan karena selain menanamnya mudah dan tumbuh di setiap musim, singkong juga menjadi makanan favorit bagi semua orang, dengan hanya sekedar di rebus atau dibakar singkong enak untuk di konsumsi. Tetapi sayangnya saat ini masyarakat sudah jarang yang menanam singkong, pasalnya setiap kali singkong ditanam, hewan liar seperti monyet kerap kali datang dan merusak tanaman ini.

Iklim di daerah ini juga mendukung untuk menanam singkong yaitu 25-30 derajat. Singkong tidak memerlukan perawatan yang khusus, Tekstur tanahnya dan air pun mendukung untuk menanam singkong. Potensi yang dimiliki oleh Desa Tarikolot selain bahan baku dan adalah sumer daya manusia. Masyarakat di pedesaan masih mengenal akan makanan tradisional dari kalangan anak-anak sampai atas sampai orang dewasa.

\section{Upaya Pelestarian Makanan Tradisional}

Upaya pelestarian makanan tradisional adalah cara untuk mencegah hilangnya makanan tersebut dari masyarakat. Upaya pelestarian makanan tradisional sebenarnya tidak harus menampilkan bentuk asli dari produk tersebut. Dengan adanya modernisasi saat ini, masyarakat akan memandang sebelah mata pada makanan tradisional. Dalam penelitian ini, peneliti melakukan inovasi pada produk tradisional kejos. Inovasi ini dimaksudkan sebagai upaya pelestarian makanan tradisional. Inovasi produk ini peneliti menggunakan bahan tambahan yaitu kacang mera dan nori (rumput laut).

Kendalanya adalah masyarakat desa Tarikolot lebih suka dengan kejos dengan rasa yang original, masyarakat elum terlalu mengenal rasa nori. Mereka masih suka dengan rasa kejos yang iasa dengan lauk pauk pendamping seperti sambal dan lalaban, seperti yang biasa mereka konsumsi.

Selain menggunakan tambahan bahan baku, peneliti juga membuat kemasan yang menarik pada kejos untuk lebih menarik perhatian masyarakat terhadap makanan tradisional ini.

Oleh karena masyarakat saat ini sangat melihat penampilan pada saat akan memutuskan untuk makan, maka peneliti bermaksud membuat kejos ini menjadi menarik untuk dikonsumsi. Peneliti membuat kemasan seperti bento untuk memberikan kesan makanan masa kini dan supaya kejos mudah dibawa kemana saja seperti bento pada umumnya.

\section{Peranan Pemerintah setempat terhadap kejos di Desa Tarikolot Kecamatan Jatinunggal Kabupaten Sumedang Provinsi Jawa Barat.}

Dalam pasal 8 j CBD mengenai konservasi mensyaratkan pihak-pihak untuk menghormati,melindungi, dan mempertahankan pengetahuan, inovasi-inovasi dan praktek masyarakat asli dan lokal yang mencerminkan gaya hidup berciri tradisional, sesuai dengan konservasi dan pemanfaatan secara berkelanjutan keanekaragaman hayati dan memajukan penerapannya secara leih luas dengan persetujuan dan keterlibatan pemilik pengetahuan inovasi-inovasi dan praktek-praktek tersebut semacam itu mendorong pembagian yang adil keuntungan yang dihasilkan dari 
pendayagunaan pengetahuan inovasi dan praktek semacam itu. Bahkan pasal-pasal selanjutnya, yaitu pasal 0, 17 ayat (2), dan pasal 18 ayat (4) mendorong pengembangan pemanfaatan sumber daya hayati secara tradisional melalui berbagai kerjasama, penelitian dan transfer teknologi. (Sri Rahayu Oktorina,2013,hlm)

Melestarikan makanan tradisional merupakan salah satu program pemerintah yang di atur dalam Undang-undang. Pemerintah sebagai lembaga yang mengatur kesejahteraan masyarakat tentunya memiliki kewajiban untuk membuat program untuk kesejahteraan masyarakat. Tetapi dengan adanya program pemerintah, masyarakat juga memiliki kewajiban untuk membantu program pemerintah tersebut dengan cara mendukung dan ikut berpatisipasi.

Program pemerintah sebenarnya sudah di atur dalam UU No 6 tentang desa, lebih spesifiknya adalah mengenai pemberdayaan masyarakat desa. menciptakan pemerdayaan masyarakat merupakan tanggung jawab bersama antara pemerintah, swasta maupun masyarakat melalui kerjasama yang serasi, selaras, dan seimbang. Apalagi pariwisata mempunyai peran penting dalam kegiatan ekonomi. (Astawan,2013,hlm.2) pemerintah desa Tarikolot sendiri sudah memiliki regulasi mengenai itu, tetapi belum terealisasikan.

Dalam program yang dirancang oleh pemerintah desa terkait pemberdayaan masyarakat adalah sebagai berikut:

1. Tahap perencanaan.

Tahap perencanaan adalah tahap pertama yang diberikan oleh pemerintah pusat mengenai pemerdayaan masyarakat, yaitu dengan cara membuat peraturan dalam upaya membantu masyarakat dengan cara memberikan bantuan secara finansial dan juga bimbingan (pelatihan) kepada masyarakat yang ingin membuat usaha. Tahap perencanaan ini sudah berjalan selama 2 tahun terakhir di Desa Tarikolot. Tetapi belum ada progress dari kedua belah pihak karena pemerintah desa masih memiliki kepentingan lain seperti memperbaiki fasilitas umum.

2. Rapat musyawarah rencana pembangunan (MUSRENBANG) yang diadakan setiap bulan januari.

Pada dasarnya sistem pemerintahan yang ada di Indonesia menganut system demokrasi, yang didalamnya adalah musyawarah. Begitupula dengan Desa Tarikolot. Setiap setahun sekali, perangkat desa melakukan musyawarah untuk mengambil keputusan.

3. Peran masyarakat dapat disampaikan secara langsung dan/atau tertulis kepada lembaga pemerintah. Dengan cara Masyarakat membuat proposal kegiatan. Dengan langkah-langkah yang dilakukan diatas, pemerintah memberikan keleluasaan kepada masyarakat. Dengan cara seperti ini masyarakat akan memunculkan ide untuk berbisnis.

Intinya, pemerintah lewat UKM maupun organisasi seharusnya melakukan sosialisasi akan pentingnya melestarikan makanan tradisional. Seperti yang dikatakan oleh Diyah Setorini dalam penelitiannya bahwa karbohidrat tidak hanya ditemui di beras, bahkan singkong pun bisa. 


\section{Kesimpulan Dan Saran Kesimpulan}

Penelitian ini menghasilkan kesimpulan yang dihasilkan dari hasil penelitian yang dilakukan oleh peneliti, yaitu sebagai berikut:

Masyarakat desa Tarikolot adalah salah satu desa yang mengalami masa sulit dalam hal menemukan beras sebagai sumber karbohidrat. oleh karena itu mereka mengkonsumsi singkong dengan cara dibuat kejos sebagai makanan pokok mereka.

Masyarakat desa Tarikolot adalah masyarakat yang bisa dibilang sulit untuk melakukan inovasi. Mereka masih menjungjung tinggi keaslian dari makanan tradisional. Sehingga untuk anak muda zaman sekarang, makanan tradisional kurang diminati.

Pemerintah Desa Tarikolot mengupayakan ingin membantu dan ingin melestarikan makanan tradisional yang ada di masyarakat.

\section{Saran}

Masyarakat perlu diberikan sosialisasi mengenai pentingnya pelestarian makanan tradisional, selain itu masyarakat desa tarikolot yang mayoritas saat ini mengkonsumsi beras sebagai makanan pokok akan sulit untuk kembali mengkonsmsi kejos. Pasalnya kejos dikenal sebagai makanan yang memiliki filosofi yang menyedihkan. Jadi masyarakat perlu merubah mindset merekeka bahwa kejos adalah makanan tradisional yang perlu dilestarikan sebagai warisan dari nenek moyang. Bukan sebagai makanan zaman paceklik atau makanan kalangan bawah.

Pemerintah dalam hal ini juga harus membantu mensosialisasikan kejos sebagai makanan yang layak untuk dilestarikan sebagai salah satu peninggalan nenek moyang.

\section{Daftar Pustaka}

Dewi,Kumala satya T. (2011). "Kearifan Lokal makanan tradisional Rekonstruksi Naskah Jawad an fungsinya dalam masyarakat". Vol:1,No:1.

Kusumaningtiyas, A., Wibisono, B., \& Kusnadi. (2013). "Penggunaan istilah makanan dan jajanan tradisional pada masyarakat di kabupaten banyuwangi". Vol:1

Maharani, Y. (2011). "Pelestarian budaya indonesia melalui pembangunan fasilitas pusat jajanan tradisional jawa barat". Skripsi. Ilmu Perpustakaan Universitas Islam Negri Hidayatullah Jakarta. Jakarta: Tidak diterbitkan

Karmadi,A.D.(2007).

Tersedia:kemendikbud.go.id: http:/kebudayaan.kemendikbud.go.id/wpcontent/uploads/sites/37/2014/11/Budaya_Lokal.pdf [selasa Desember 2015]

Winarmo, F. (2004). Kimia Pangan dan Gizi. Jakarta: PT Gramedia.

Salim, E. (2011). Mengolah Singkong Menjadi Tepung Mocaf. Yogyakarta: Andi Offset. 
Widowati Indah. (2013). Peluang Usaha Pembibitan Singkong Guna Mendukung Pengembangan Agroindustri Berbahan Baku Singkong. Universitas Pembangunan Nasional. Sleman Yogyakarta: Tidak Diterbitkan

Hidayah, N. (2011). "Kesiapan Fsikologis Masyarakat Pedesaan Dan Perkotaan Menghadapi Difersifikasi Pangan Pokok". Skripsi.Fakultas Psikologi Universitas Ahmad Dahlan. Yogyakarta: Tidak diterbitkan

Creswell, J. W. (2013). Research design Pendekatan Kualitatif,Kuantitatif, dan mixed. Yogyakarta: Pustaka Pelajar.

Moleong, L. J. (2014). Metodologi Penelitian Kualitatif. Bandung: PT Remaja Rosdakarya.

Astawan, M. (2013). Jangan Takut Makan Enak Dengan Makanan Tradisional. Jakarta: Kompas.

Sri Rahayu Oktoberina. (2013). "Landasan hukum kerjasama apakah yang dapat dikembangkan untuk memberdayakan masyarakat". Bandung: Tidak diteritkan

Setyorini,Diyah. (2012).’Peluang Bisnis Gaplek”.Tugas akhir. STMIK AMIKOM Yogyakarta: Tidak diterbitkan 